\title{
An exploration of the factors that influence footwear selection in women with Rheumatoid Arthritis - a qualitative study
}

\author{
Serena Naidoo*, Stephanie Anderson, Joanna Mills, Stephanie Parsons, Stephanie Breeden, Emma Bevan, \\ Camilla Edwards, Simon Otter
}

From Society of Chiropodists and Podiatrists Annual Conference 2010

Bournemouth, UK. 21-23 October 2010

\section{Background}

Studies report that women with Rheumatoid Arthritis (RA) are not wearing therapeutic footwear. It is likely they are wearing normal retail footwear. Previous research gives limited information on people's perceptions on the relationships that exist between retail footwear, well-being and quality of life (QOL). This study aimed to explore these perceptions and to identify the factors influencing footwear selection.

\section{Methods}

Eleven women with RA wearing retail footwear were recruited from an out-patient podiatry clinic in the south east of England. Semi-structured interviews were carried out and a hermeneutical approach; interpretative phenomenological analysis of transcripts occurred to identify recurring themes.

\section{Results}

Six main themes were revealed from the analysis. These included: (1) the nature of foot complaints and deformities, (2) aesthetic appearance and design of footwear, (3) body image, (4) psychosocial aspects, (5) Perceptions of footwear and (6) the therapeutic value of retail shoes.

\section{Conclusions}

Retail footwear for these women with RA has impacted on their individuality which has been shown to link significantly with their body images. Whilst footwear itself has not impacted solely on the well-being of these

University of Brighton, Brighton, UK

(C) 2010 Naidoo et al; licensee BioMed Central Ltd. This is an open access article distributed under the terms of the Creative Commons Attribution License (http://creativecommons.org/licenses/by/2.0), which permits unrestricted use, distribution, and reproduction in any medium, provided the original work is properly cited. women; the disease process has. These consequences have been identified in their quality of life.

Published: 20 December 2010

doi:10.1186/1757-1146-3-S1-018

Cite this article as: Naidoo et al:: An exploration of the factors that qualitative study. Journal of Foot and Ankle Research 2010 3(Suppl 1):018. influence footwear selection in women with Rheumatoid Arthritis - a
Submit your next manuscript to BioMed Central and take full advantage of:

- Convenient online submission

- Thorough peer review

- No space constraints or color figure charges

- Immediate publication on acceptance

- Inclusion in PubMed, CAS, Scopus and Google Scholar

- Research which is freely available for redistribution

Submit your manuscript at www.biomedcentral.com/submit
() Biomed Central

\section{() Biomed Central}

